\title{
Temporal variations in the physicochemical characterization of Malakandher River waste water
}

Laiq Zada ${ }^{*}$, Mohammad Sajjad ${ }^{2}$, Shafiullah $^{3}$, Rafiullah ${ }^{4}$, Faraz Ali Shah ${ }^{3}$, Fawad Ali ${ }^{5}$, Abid Kamal ${ }^{1}$, Haroon Ilahi ${ }^{4}$ and Kiran Hidayat ${ }^{6}$

1. Department of Soil and Environmental Sciences, The University of Agriculture Peshawar-Pakistan

2. Department of Plant Breeding and Genetics, The University of Agriculture Peshawar-Pakistan

3. Department of Horticulture, The University of Agriculture Peshawar-Pakistan

4. Department of Agriculture (Soil Science), The university of Swabi, KPK-Pakistan

5. Department of Water Management, The University of Agriculture Peshawar-Pakistan

6. Department of Chemistry, Women University of Swabi-Pakistan

*Corresponding author's email: zadalaiq259@gmail.com

Citation

Laiq Zada, Mohammad Sajjad, Shafiullah, Rafiullah, Faraz Ali Shah, Fawad Ali, Abid Kamal, Haroon Ilahi and Kiran Hidayat. Temporal variations in the physicochemical characterization of Malakandher River waste water. Pure and Applied Biology. Vol. 10, Issue 4, pp1104-1108. http://dx.doi.org/10.19045/bspab.2021.100115

Received: 22/10/2020 Revised: 04/01/2021

Accepted: $11 / 01 / 2021$

Online First: 13/01/2021

\section{Abstract}

Waste water of Malakandher River was evaluated to assess its suitability for irrigation. Samples from Malakandher River were collected and analyzed for $\mathrm{pH}$, temperature, total suspended solids (TSS), biological oxygen demand (BOD), heavy metals chromium (Cr) and lead (Pb). Result showed that there were significant variations among all of the samples of waste water. Temperature varied from $\left(17.95\right.$ to $\left.27.82^{\circ} \mathrm{C}\right), \mathrm{pH}\left(5.55\right.$ to $\left.7.02 \mathrm{molL}^{-1}\right), \mathrm{EC}\left(0.72\right.$ to $\left.0.95 \mathrm{dSm}^{-1}\right)$ and $\mathrm{Cr}(0.12$ to $\left.0.3 \mathrm{mgL}^{-1}\right)$. Mean values of these parameters were within the acceptable limits of National Environmental Quality Standards (NEQS). Similarly total suspended solids (TSS) varied from 75 to $725 \mathrm{mgL}^{-1}$, biological oxygen demand (BOD) 80 to $290 \mathrm{mgL}^{-1}$ and concentration of heavy metal lead $(\mathrm{Pb}) 0.42$ to $1.32 \mathrm{mgL}^{-1}$ and their mean values were above the standards value of NEQS. All industries discharge their effluents without pretreatment and farmer apply this waste water to field directly. Thus it can be concluded if this water is discharged to agricultural fields may cause phytotoxicity and health issues. If the crops are receiving such water is utilized by human beings or animals.

Keywords: BOD; EC; Heavy metals; pH; Waste water

\section{Introduction}

Water is an indispensible compound for an ecosystem. It is required for the growth and survival of all living organisms on the earth surface. Earth is the only planet having $70 \%$ of water. Such water is contaminated due to industrialization, use of fertilizers in agriculture and increased human population.
Thus drinking water must be checked at regular interval of time, as human beings are suffering from various water born diseases due to using contaminated drinking water. Fully understanding of biological phenomenon is difficult because, chemistry of water explain the general hydro biological relationship and also about the 
metabolism of the ecosystem [1]. Increase in the population of developing countries in the urban sector, a huge amount of freshwater are offloaded into commercial, domestic and industrial sectors for the sake of better living standards of the residents. As a result waste water is produced on large scale [2-4]. Pakistan is an agriculture country, dependent on system of canal irrigation. This system does not provide sufficient water for crop water requirement to be fulfilled, thus poor quality of ground water is used. This lead to serious problem of sodicity, salinity and as a result low agriculture production [5]. Natural water bodies are polluted due to no or little discharge of waste water. Waste water is the sole choice for the Farmers of urban areas of developing countries to use it for irrigation. Concentrated waste water is used by them because it is cheaper, more reliable and provides sufficient nutrients than the sources of other water $[6,7]$. As the levels of pollutants increases in river water result an increase in chemical oxygen demand (COD), biological oxygen demand (BOD), total suspended solids (TSS), total dissolved solids (TDS),) and toxic heavy metals such as $\mathrm{Cr}$, $\mathrm{Cd}, \mathrm{Ni}$ and $\mathrm{Pb}$ making such type of water not fit for irrigation, drinking and aquatic organisms. In developing countries $60 \%$ of population is depriving to drink pure water [8]. Now a day's about 2.4 billion people are lacking appropriate sanitation and about 3.4 million people are dying from water born diseases each year worldwide [9]. If these effluents are used for irrigation for long time, it will contaminate crops and soil to such an extent that it will become toxic to plants and will cause deterioration of soil $[\mathbf{1 0}, \mathbf{1 1}]$.

\section{Methods and Materials}

The experiment was performed in Peshawar, Malakandher during 2011 to analyze the waste water of Malakandher River for its physicochemical characterization and to check temporal variations in their properties. Waste water were collected from the selected spot of the Malakandher River in the plastic bottles (two bottles at five days interval morning time and two bottles at evening time) for two consecutive months. The samples were analyzed in the laboratory for temperature, $\mathrm{pH}, \mathrm{EC}, \mathrm{TSS}, \mathrm{BOD}$ and heavy metals. The samples were properly labeled and bring to the laboratory of Soil and Environmental Sciences, The University of Agriculture Peshawar for analysis.

The data were statistically analyzed by CR design and the results were compared to the National Environmental Quality Standards (NEQS). The following parameters were studied in the laboratory.

\section{pH}

It was determined by using $\mathrm{pH}$ meter. The instrument was first standardized by buffer solution ( $\mathrm{pH} 4-9)$. To note $\mathrm{pH}$ of waste water the probe of $\mathrm{pH}$ meter was dipped in the samples [12].

\section{Electrical conductivity (EC) meter}

EC of waste water was determined by using $\mathrm{EC}$ meter. To note the EC value first of all the instrument was rinsed with distills water and then dipped in the samples [12].

\section{Total suspended solids (TSS)}

Total suspended solids of waste water was calculated by the formula of [13] as given as; Total suspended solids $\left(\mathrm{mgL}^{-1}\right)=$ Total solids-Dissolved solids

\section{Biological oxygen demand (BOD)}

Biological oxygen demand was determined by using chemical method [14]. In this method each sample was poured into 6 bottles such as one $\mathrm{mL}$, two $\mathrm{ml}$ and similarly three $\mathrm{mL}$ into each 2 bottles. After that all of the bottles were refilled with dilution water to make it air tight. Three samples out of six bottles of each sample was put in dark for five consecutive days in incubator at $20{ }^{\circ} \mathrm{C}$, while three were processed for Initial DO. All of the BOD bottles were filled with one $\mathrm{mL}$ phosphate buffer solution and lids were tied again. To make the bottles mixed thoroughly with one $\mathrm{mL}$ phosphate buffer solution, extra 
solutions was discarded and shake the bottles well. Such process is repeated with $\mathrm{H}_{2} \mathrm{SO}_{4}$ and alkaline ionized iodide reagent. Starch indicator was added in each bottle @ of 0.5 $\mathrm{mL} / 300 \mathrm{~mL}$ and $100 \mathrm{~mL}$ solution was discarded from each bottles. The solution was titrated with sodium thiosulphate. BOD can be determined by using the following formula;

$$
\text { BOD }\left(\mathrm{mg} \mathrm{L}^{-1}\right)=\frac{\text { Initial Do-Final Do }}{\text { sample volume }} \times 300
$$

\section{Temperature}

To measure temperature of waste water a calibrated mercury thermometer $\left(10-100{ }^{\circ} \mathrm{C}\right)$ was used. Thermometer was dipped in water samples and record temperature until the reading become constant. After that thermometer washed away thoroughly with distilled water each sample analysis [15].

\section{Heavy metals}

Heavy metals $(\mathrm{Cr}, \mathrm{Pb})$ concentration of waste water samples found out by the use of standard solution of the metals and their respective cathode lamp.

\section{Results and Discussion}

The result showed significant variations for $\mathrm{pH}$ of waste water samples, when samples were collected at different time's interval as well as different times of the day. It varied from 5.55 to 7.02 (Table 1). The higher $\mathrm{pH}$ was recorded at morning time as compared to evening. Mean value of $\mathrm{pH}$ (6.28) lied within the acceptable range of National Environmental Quality Standards (NEQS) is 6 to 10. This result was supported by [16]. It is also cleared from the table that EC of waste water showed significant variation when samples were collected at different time's interval as well as different times of the day. It varied from 0.72 to $0.95 \mathrm{dSm}^{-1}$ (Table1). Higher EC was observed when sample was taken during evening. Mean value of EC $\left(0.83 \mathrm{dSm}^{-1}\right)$ lies within the acceptable range of NEQS and can be used for the purpose of irrigation [12]. Similarly Total suspended solids (TSS) range from 75 to $725 \mathrm{mgL}^{-}$ ${ }^{1}$ (Table 1) showed significant variations.
Mean value of TSS of Malakandher River waste water was $\left(400 \mathrm{mgL}^{-1}\right)$ above acceptable limit of NEQS for TSS $\left(150 \mathrm{mgL}^{-}\right.$ $\left.{ }^{1}\right)$. If such water is directly applied to agriculture fields or stream or river would cause serious problems to aquatic life [16]. The result of Biological oxygen demand (BOD) also showed significant variations among all the samples and it varied from 80 to $290 \mathrm{mgL}^{-1}$ (Table 1). The high value of BOD was observed when samples were taken during evening indicating that water is more polluted during evening time as compared to morning. Mean value of BOD $\left(193 \mathrm{mgL}^{-1}\right)$ was above the acceptable limit of NEQS (80 $\mathrm{mg} \mathrm{\textrm {L } ^ { - 1 }}$ ). It indicates if such waste water mixed with stream water or rivers, its effects will be adverse on aquatic life due to depleted level of $\mathrm{O}_{2}$ in water $\left.[16,17]\right)$. They had drawn similar conclusions. Temperature varied from 17.95 to $27.82^{\circ} \mathrm{C}$ (Table 1) showed significant variations when samples were collected in different time's interval as well as in different time of day. The variation in evening temperature was higher than that of morning. This variation is due sunshine in after noon compared to morning when time was early and the earth surface was cool. According to NEQS the acceptable range of temperature for irrigation is $40^{\circ} \mathrm{C}$ and over all mean temperature of Malakandher River waste water was $23.61^{\circ} \mathrm{C}$ lies within the acceptable range of NEQS [16]. Heavy metal chromium $(\mathrm{Cr})$ varied from 0.12 to $0.3 \mathrm{mgL}^{-}$ ${ }^{1}$ (Table 1) showed significant variation when samples were collected in different interval as well as in different time of day. According to NEQS acceptable range for $\mathrm{Cr}$ is $1.0 \mathrm{mgL}^{-}$ 1 , while the mean concentration of $\mathrm{Cr}$ in Malakandher River waste water was 0.23 $\mathrm{mgL}^{-1}$ lies within the acceptable limit of NEQS. Similarly the result of heavy metal lead $(\mathrm{Pb})$ range from 0.42 to $1.325 \mathrm{mgL}^{-1}$ showed significant variations among all of the samples of waste water (Table 1). Mean value of $\mathrm{Pb}$ was observed $0.872 \mathrm{mgL}^{-1}$ was 
above the acceptable limit of NEQS which is $0.5 \mathrm{mgL}^{-1}$. [18].

Table 1. Studied parameters of Malakandher River waste water

\begin{tabular}{|c|c|c|c|c|c|c|c|}
\hline $\begin{array}{c}\text { Time } \\
\text { intervals(days) }\end{array}$ & pH & $\begin{array}{c}\mathbf{E C} \\
\left(\mathbf{d S m}^{-1}\right)\end{array}$ & $\begin{array}{c}\text { TSS } \\
\left(\mathrm{mgL}^{-1}\right)\end{array}$ & $\begin{array}{c}\text { BOD } \\
\left(\mathrm{mgL}^{-1}\right)\end{array}$ & $\begin{array}{l}\text { Temp } \\
\left({ }^{\circ} \mathrm{C}\right)\end{array}$ & $\begin{array}{l}\text { Cr conc } \\
\left(\mathrm{mgL}^{-1}\right)\end{array}$ & $\begin{array}{l}\text { Pb conc } \\
\left(\mathrm{mgL}^{-1}\right)\end{array}$ \\
\hline $0---------5$ & $7.02 \mathrm{a}$ & $0.8725 \mathrm{c}$ & $300 \mathrm{bcd}$ & $80 \mathrm{f}$ & $27.6 a b$ & $0.18 b c$ & $0.465 \mathrm{c}$ \\
\hline 6---------10 & $6.80 \mathrm{ab}$ & $0.845 \mathrm{~d}$ & $725 a$ & $101.25 \mathrm{ef}$ & $27.82 \mathrm{a}$ & $0.1725 b c$ & $1.235 \mathrm{ab}$ \\
\hline 11-------15 & $6.62 \mathrm{abc}$ & $0.897 \mathrm{~b}$ & 462.5abcd & 150def & $27.4 \mathrm{~b}$ & $0.345 \mathrm{a}$ & $0.67 b c$ \\
\hline 16-------20 & $6.52 \mathrm{abc}$ & $0.955 \mathrm{a}$ & $75 \mathrm{~d}$ & 190bcde & $24.92 \mathrm{c}$ & $0.2375 a b c$ & $0.675 \mathrm{c}$ \\
\hline 21-------25 & $6.51 \mathrm{abc}$ & $0.725 f$ & $112.5 \mathrm{~cd}$ & $182.5 \mathrm{cde}$ & $25.1 \mathrm{c}$ & $0.2825 \mathrm{ab}$ & $0.44 c$ \\
\hline 26-------30 & $6.76 \mathrm{ab}$ & $0.897 \mathrm{~b}$ & 400abcd & 190bcde & $23.15 d$ & $0.17 b c$ & $0.88 \mathrm{abc}$ \\
\hline 31-------35 & $6.14 c$ & $0.882 b c$ & $650 \mathrm{ab}$ & $250 \mathrm{abc}$ & $20.9 \mathrm{e}$ & $0.2875 \mathrm{ab}$ & $1.205 \mathrm{ab}$ \\
\hline $36-----40$ & $6.39 b c$ & $0.767 \mathrm{e}$ & $125 \mathrm{~cd}$ & $275 a b c$ & $22.05 \mathrm{~g}$ & $0.27 \mathrm{abc}$ & $0.705 b c$ \\
\hline 41--------45 & $5.55 \mathrm{~d}$ & $0.935 \mathrm{a}$ & 475abcd & $290 a$ & $19.27 \mathrm{~g}$ & $0.125 \mathrm{c}$ & $0.42 \mathrm{c}$ \\
\hline 46-------50 & $6.57 \mathrm{abc}$ & $0.892 \mathrm{bc}$ & $525 \mathrm{abc}$ & 217abcd & $17.95 \mathrm{~h}$ & $0.255 \mathrm{abc}$ & $1.325 \mathrm{a}$ \\
\hline Means & 6.28 & 0.83 & 400 & 193 & 23.61 & 0.23 & 0.872 \\
\hline NEQS,2000 & $6-10$ & 1.5 & 150 & 80 & 40 & 1.0 & 0.5 \\
\hline $\begin{array}{l}\text { LSD for time } \\
\text { interval }\end{array}$ & 0.26 & 0.0096 & 188.5 & 40.43 & 0.12 & 0.055 & 0.253 \\
\hline $\begin{array}{l}\text { LSD for time of } \\
\text { the day }\end{array}$ & 0.58 & 0.02 & 419.44 & 90.40 & 0.27 & 0.123 & 0.56 \\
\hline
\end{tabular}

Means followed by similar letter are not significantly different at $p \leq 0.05 \%$ level

\section{Conclusion and Recommendations}

On the basis of our results it was concluded that $\mathrm{pH}, \mathrm{EC}$, temperature and heavy metal $(\mathrm{Cr})$ of the Malakandher River waste water were within the acceptable limit of the standard values so it did not pose any major threat to the environment. Nearly all samples showed high BOD, TSS and heavy metal lead $(\mathrm{Pb})$ concentration. This water on entering to fresh water sources may adversely affect aquatic life and not fit for irrigation with respect to lead $(\mathrm{Pb})$ whereas chromium $(\mathrm{Cr})$ is not a problem. Thus waste water should be treated before using it for irrigation or entering surface water supply. Beside this experimentation on different crops using waste water should be carried to evaluate the toxicity or beneficial effects.

\section{Authors' contributions}

Conceived and designed the experiments: L Zada \& M Sajjad, Performed the experiments: L Zada \& Shafiullah, Analyzed the data: L Zada \& A Kamal, Contributed materials/ analysis/ tools: M Sajjad, Rafiullah \& H Ilahi, Wrote the paper: L Zada, FA Shah \& K Hidayat.

\section{Acknowledgment}

The authors are very thankful to Prof. Dr Muhammad Jamal Khan (retired) for his supervision and advice during this research experiment.

\section{References}

1. Basavaraja S, Hiremath SM, Murthy KNS, Chandrashekarappa KN, Patel AN \& Puttiah ET (2011). Analysis of Water Quality Using Physico-Chemical Parameters Hosahalli Tank in Shimoga District, Karnataka, India. Global $J$ of Sci Frontier, Res 1(3): 31-34.

2. Lazarova V \& Bahri A (2005). Water Reuse for Irrigation: Agriculture, Landscapes, and Turf Grass. CRC Press, Boca Raton, USA.

3. Qadir M, Wichelns D, Raschid SL, Minhas PS, Drechsel P, Bahri A \& McCornick P (2007). Agricultural use of 
marginal quality water opportunities and challenges. In: Molden, D. (Ed.), Water for Food, Water for Life: A Comprehensive Assessment of Water Management in Agriculture Earthscan, London, UK.

4. Burton AT, Leverenz F, Tsuchihashi H \& Tchobanoglous RG (2007) Water Reuse: Issues, Technologies and Applications (McGraw-Hill). Metcalf \& Eddy Inc.

5. Arif M (1994). Effect of industrial effluent and sewage water on plant composition and soil properties", Institute of food Science and Technology, University of Agriculture, Faisalabad.

6. Keraita BN \& Drechsel P (2004). Agricultural use of untreated urban wastewater in Ghana. In: Scott CA, Faruqui NI, Raschid-Sally L (Eds.), Wastewater Use in Irrigated Agriculture. CABI Publishing Wallingford, UK: 101112.

7. Scott CA, Faruqui NI \& Raschid SL (2004). Wastewater use in irrigated agriculture: management challenges in developing countri. CABI Publishing, UK.

8. Chillers J \& Henrik A (1996). Effect of contaminated water. Global Water Hazards 25: 25-27.

9. Anonymous (2001). The NEWS International Water Quality Assessment.

10. Quinn BF \& Syres JK (1978). Surface irrigation of pasture with treated sewage effluent, heavy metal content of sewage effulent, sludge, soil and pasture, Newzealand. J of Agri Res 21: 435-442.

11. Hemkes OJ, Kemp A \&Van B LW (1980). Accumulation of Heavy metals in soil due to annual dressing of sewage sludge. Netherlands J of Agri Scs 28: 228-238.

12. Richards LA (1954). Diagnosis and improvement of saline and alkali soils. Hand Book 60. United States Department of Agriculture.

13. Hamer MJ (1986). Laboratory Chemical analysis In: water and waste water technology, $2^{\text {nd }}$ Ed.John Wiley \& Sons New York.

14. Clescri LS, Greenberg AE \& Trussell R (1989). Standard methods for examination of water and waste water. $17^{\text {th }}$ Ed.amer. Publ. Health assoc. and Amer. Water works Assoc 754.

15. EPA (1998). Methods for chemical analysis of industrial effluents.

16. Shah H (1999). Integrated approaches for sustainable industrial development in HAIE. Internship Report. Department of Environment, Planning and Management, University of Peshawar.

17. Khan S \& Noor M (2002). Investigation of pollutants in wastewater of Hayatabad Industrial Estate Peshawar. Pak J of Agri Scs 2: 457-461.

18. Banaras M (1994). Environmental monitoring of HAIE. M.Sc thesis submitted to the Department of Environment, Planning and Management, University of Peshawar. 